Yee Seng Tan and Edward R.T. Tiekink*

\title{
Crystal structure of catena-poly $\left\{\left(\mu_{2}-N^{1}, N^{2}\right.\right.$-bis[(pyridin-4-yl)methyl] ethanediamide- $\left.\mathrm{K}^{2} \mathrm{~N}: \mathrm{N}^{\prime}\right)$-bis $\left(O, \mathrm{O}^{\prime}\right.$-di-isopropyldithiophosphato- $\left.{ }^{1} S\right)$ zinc(II)\} - acetonitrile (1/1), $\mathrm{C}_{26} \mathrm{H}_{42} \mathrm{~N}_{4} \mathrm{O}_{6} \mathrm{P}_{2} \mathrm{~S}_{4} \mathrm{Zn} \cdot \mathrm{C}_{2} \mathrm{H}_{3} \mathrm{~N}$
}
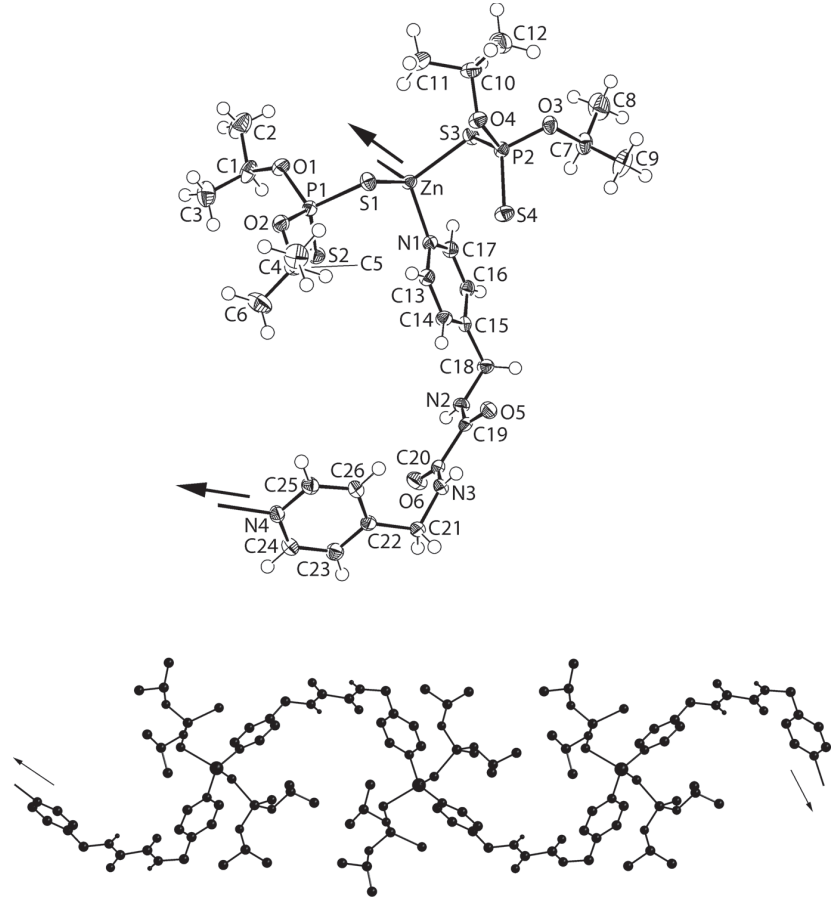

https://doi.org/10.1515/ncrs-2019-0650

Received September 3, 2019; accepted October 16, 2019; available online November 2, 2019

\section{Abstract}

$\mathrm{C}_{28} \mathrm{H}_{45} \mathrm{~N}_{5} \mathrm{O}_{6} \mathrm{P}_{2} \mathrm{~S}_{4} \mathrm{Zn}, \quad$ monoclinic, $P 2_{1} / c \quad$ (no. 14), $a=7.73670(10) \AA, \quad b=21.56370(10) \AA, \quad c=23.1184(2) \AA$, $\beta=99.121(1)^{\circ}, \quad V=3808.12(6) \AA^{3}, \quad Z=4, \quad R_{\mathrm{gt}}(F)=0.0210$, $w R_{\text {ref }}\left(F^{2}\right)=0.0580, T=100(2) \mathrm{K}$.

\section{CCDC no.: 1959644}

Table 1 contains crystallographic data and Table 2 contains the list of the atoms including atomic coordinates and displacement parameters.

*Corresponding author: Edward R.T. Tiekink, Research Centre for Crystalline Materials, School of Science and Technology, Sunway University, 47500 Bandar Sunway, Selangor Darul Ehsan, Malaysia, e-mail: edwardt@sunway.edu.my.https://orcid.org/0000-00031401-1520

Yee Seng Tan: Research Centre for Crystalline Materials, School of Science and Technology, Sunway University, 47500 Bandar Sunway, Selangor Darul Ehsan, Malaysia
Table 1: Data collection and handling.

\begin{tabular}{ll}
\hline Crystal: & Yellow prism \\
Size: & $0.13 \times 0.10 \times 0.06 \mathrm{~mm}$ \\
Wavelength: & Cu $K \alpha$ radiation $(1.54184 \AA$ A $)$ \\
$\mu:$ & $4.11 \mathrm{~mm}^{-1}$ \\
Diffractometer, scan mode: & XtaLAB Synergy, $\omega$ \\
$\theta_{\text {max }}$, completeness: & $67.1^{\circ},>99 \%$ \\
$N(h k l)_{\text {measured }}, N(h k l)_{\text {unique }}, R_{\text {int }}:$ & $42746,6793,0.019$ \\
Criterion for $I_{\text {obs }}, N\left(h k l_{\text {gt }}:\right.$ & $I_{\text {obs }}>2 \sigma\left(I_{\text {obs }}\right), 6561$ \\
$N(\text { param })_{\text {refined }}:$ & 430 \\
Programs: & CrysAlis ${ }^{\text {PRO }}[1]$, SHELX [2, 3], \\
& WinGX/ORTEP [4] \\
\hline
\end{tabular}

Table 2: Fractional atomic coordinates and isotropic or equivalent isotropic displacement parameters $\left(\AA^{2}\right)$.

\begin{tabular}{lrrrr}
\hline Atom & $\boldsymbol{x}$ & $\boldsymbol{y}$ & $\boldsymbol{Z}$ & $\boldsymbol{U}_{\text {iso }} / \boldsymbol{U}_{\text {eq }}$ \\
\hline Zn & $0.14526(2)$ & $0.27129(2)$ & $0.27222(2)$ & $0.01304(6)$ \\
S1 & $0.38897(4)$ & $0.24625(2)$ & $0.23149(2)$ & $0.01615(8)$ \\
S2 & $0.04782(4)$ & $0.18846(2)$ & $0.13725(2)$ & $0.01786(8)$ \\
S3 & $0.18841(4)$ & $0.32602(2)$ & $0.36011(2)$ & $0.01598(8)$ \\
S4 & $0.30265(4)$ & $0.43011(2)$ & $0.26352(2)$ & $0.01813(8)$ \\
P1 & $0.28829(4)$ & $0.17728(2)$ & $0.17662(2)$ & $0.01424(8)$ \\
P2 & $0.35930(4)$ & $0.39163(2)$ & $0.34014(2)$ & $0.01324(8)$ \\
O1 & $0.31846(13)$ & $0.11522(5)$ & $0.21361(4)$ & $0.0199(2)$ \\
O2 & $0.42539(13)$ & $0.16829(5)$ & $0.13249(4)$ & $0.0177(2)$ \\
O3 & $0.38062(12)$ & $0.43939(4)$ & $0.39351(4)$ & $0.0165(2)$ \\
O4 & $0.55075(12)$ & $0.36273(4)$ & $0.34833(4)$ & $0.0165(2)$ \\
O5 & $-0.15909(13)$ & $0.49101(5)$ & $0.03897(4)$ & $0.0172(2)$ \\
O6 & $-0.45124(14)$ & $0.41764(5)$ & $-0.07211(4)$ & $0.0240(2)$ \\
N1 & $-0.03786(15)$ & $0.31956(5)$ & $0.21747(5)$ & $0.0140(2)$ \\
N2 & $-0.39940(15)$ & $0.43209(5)$ & $0.04544(5)$ & $0.0156(2)$ \\
H2N & $-0.4874(17)$ & $0.4121(7)$ & $0.0261(7)$ & $0.019^{*}$ \\
N3 & $-0.20479(16)$ & $0.47374(5)$ & $-0.07837(5)$ & $0.0163(2)$ \\
H3N & $-0.1151(17)$ & $0.4924(7)$ & $-0.0585(7)$ & $0.020^{*}$ \\
N4 & $0.02107(15)$ & $0.30624(5)$ & $-0.20220(5)$ & $0.0147(2)$ \\
N5 & $0.2613(2)$ & $0.36616(7)$ & $0.03191(7)$ & $0.0377(4)$ \\
C1 & $0.2049(2)$ & $0.06063(7)$ & $0.20077(7)$ & $0.0221(3)$ \\
H1 & 0.0797 & 0.0743 & 0.1937 & $0.026^{*}$ \\
C2 & $0.2367(3)$ & $0.02105(8)$ & $0.25512(8)$ & $0.0361(4)$ \\
H2A & 0.3545 & 0.0032 & 0.2594 & $0.054^{*}$ \\
H2B & 0.1499 & -0.0124 & 0.2519 & $0.054^{*}$ \\
H2C & 0.2265 & 0.0466 & 0.2895 & $0.054^{*}$ \\
C3 & $0.2460(2)$ & $0.02731(8)$ & $0.14717(8)$ & $0.0292(4)$ \\
H3A & 0.2200 & 0.0546 & 0.1130 & $0.044^{*}$ \\
& & & &
\end{tabular}


Table 2 (continued)

\begin{tabular}{|c|c|c|c|c|}
\hline Atom & $x$ & $y$ & $z$ & $U_{\text {iso }} * / U_{\text {eq }}$ \\
\hline $3 B$ & 0.1744 & -0.0103 & 0.1406 & $0.044^{*}$ \\
\hline $\mathrm{H} 3 \mathrm{C}$ & 0.3702 & 0.0160 & 0.1531 & $0.044^{*}$ \\
\hline $\mathrm{C} 4$ & $0.4273(2)$ & $0.21403(7)$ & $0.08568(6)$ & $0.0200(3)$ \\
\hline $\mathrm{H} 4$ & 0.3571 & 0.2511 & 0.0936 & $0.024^{*}$ \\
\hline $\mathrm{C} 5$ & $0.6156(2)$ & $0.23289(8)$ & $0.08609(8)$ & $0.0281(4)$ \\
\hline $\mathrm{H} 5 \mathrm{~A}$ & 0.6638 & 0.2498 & 0.1246 & $0.042^{*}$ \\
\hline $\mathrm{H} 5 \mathrm{~B}$ & 0.6211 & 0.2645 & 0.0560 & $0.042 *$ \\
\hline $\mathrm{H} 5 \mathrm{C}$ & 0.6840 & 0.1966 & 0.0779 & $0.042^{*}$ \\
\hline $\mathrm{C} 6$ & $0.3458(2)$ & $0.18447(9)$ & $0.02869(7)$ & $0.0296(4)$ \\
\hline $\mathrm{H} 6 \mathrm{~A}$ & 0.4131 & 0.1476 & 0.0214 & $0.044^{*}$ \\
\hline $\mathrm{H} 6 \mathrm{~B}$ & 0.3463 & 0.2142 & -0.0034 & $0.044^{*}$ \\
\hline $\mathrm{H} 6 \mathrm{C}$ & 0.2249 & 0.1725 & 0.0311 & $0.044^{*}$ \\
\hline $\mathrm{C} 7$ & $0.23637(19)$ & $0.48154(7)$ & $0.40048(7)$ & $0.0207(3)$ \\
\hline $\mathrm{H} 7$ & 0.1301 & 0.4697 & 0.3721 & $0.025^{\star}$ \\
\hline $\mathrm{C} 8$ & $0.1990(2)$ & $0.47379(9)$ & $0.46193(8)$ & $0.0346(4)$ \\
\hline $\mathrm{H} 8 \mathrm{~A}$ & 0.1604 & 0.4312 & 0.4674 & $0.052^{*}$ \\
\hline $\mathrm{H} 8 \mathrm{~B}$ & 0.1066 & 0.5028 & 0.4687 & $0.052^{*}$ \\
\hline $\mathrm{H} 8 \mathrm{C}$ & 0.3055 & 0.4824 & 0.4898 & $0.052^{*}$ \\
\hline $\mathrm{C} 9$ & $0.2907(2)$ & $0.54666(7)$ & $0.38731(9)$ & $0.0330(4)$ \\
\hline $\mathrm{H} 9 \mathrm{~A}$ & 0.3959 & 0.5581 & 0.4147 & $0.049 *$ \\
\hline H9B & 0.1958 & 0.5755 & 0.3916 & $0.049^{*}$ \\
\hline $\mathrm{H} 9 \mathrm{C}$ & 0.3158 & 0.5486 & 0.3471 & $0.049^{*}$ \\
\hline C10 & $0.61769(19)$ & $0.32944(7)$ & $0.40286(6)$ & $0.0195(3)$ \\
\hline $\mathrm{H} 10$ & 0.5234 & 0.3273 & 0.4278 & $0.023^{*}$ \\
\hline C11 & $0.6630(2)$ & $0.26454(8)$ & $38597(8)$ & $0.0310(4)$ \\
\hline $11 \mathrm{~A}$ & 0.5651 & 0.2472 & 0.3587 & $0.047^{\star}$ \\
\hline $\mathrm{H} 11 \mathrm{~B}$ & 0.6854 & 0.2386 & 0.4211 & $0.047^{*}$ \\
\hline $\mathrm{H} 11 \mathrm{C}$ & 0.7678 & 0.2657 & 71 & $0.047^{*}$ \\
\hline C12 & $0.7703(2)$ & $36561(8)$ & $0.43494(7)$ & $0.0280(3)$ \\
\hline $\mathrm{H} 12 \mathrm{~A}$ & 0.8631 & 0.3680 & 0.4107 & $0.042^{\star}$ \\
\hline $\mathrm{H} 12 \mathrm{~B}$ & 0.8153 & 0.3447 & 0.4719 & $0.042^{\star}$ \\
\hline $\mathrm{H} 12 \mathrm{C}$ & 0.7318 & 0.4076 & 0.4431 & $0.042^{\star}$ \\
\hline $\mathrm{C} 13$ & $0.00384(18)$ & $0.34232(6)$ & $0.16738(6)$ & $0.0153(3)$ \\
\hline $\mathrm{H} 13$ & 0.1141 & & 0.1569 & $0.018^{\star}$ \\
\hline C14 & $0.10758(18)$ & $0.38026(6)$ & $0.13071(6)$ & $0.0155(3)$ \\
\hline $\mathrm{H} 14$ & -0.0737 & & 0.0957 & $0.019^{\star}$ \\
\hline C15 & $-0.27014(18)$ & $0.39560(6)$ & $0.14527(6)$ & $0.0137(3)$ \\
\hline C16 & $-0.31376(18)$ & $0.37144(6)$ & $0.19675(6)$ & $0.0154(3)$ \\
\hline $\mathrm{H} 16$ & -0.4244 & 0.3802 & 0.2078 & $0.018^{\star}$ \\
\hline $\mathrm{C} 17$ & $-0.19424(19)$ & $0.33453(6)$ & $0.23167(6)$ & $0.0162(3)$ \\
\hline $\mathrm{H} 17$ & -0.2239 & 0.3190 & 0.2673 & $0.019^{\star}$ \\
\hline C18 & $-0.39457(18)$ & $.43947(7)$ & $10838(6)$ & $.0165(3)$ \\
\hline $\mathrm{H} 18 \mathrm{~A}$ & -0.5139 & 0.4329 & 0.1176 & $0.020^{\star}$ \\
\hline $\mathrm{H} 18 \mathrm{~B}$ & -0.3600 & 0.4826 & 0.1194 & $0.020^{\star}$ \\
\hline C19 & $-0.28532(18)$ & $0.45962(6)$ & $0.01659(6)$ & $0.0146(3)$ \\
\hline $\mathrm{C} 20$ & $-0.32338(19)$ & $0.44770(6)$ & $-0.05001(6)$ & $0.0161(3)$ \\
\hline $\mathrm{C} 21$ & $-0.2181(2)$ & $0.46908(7)$ & $0.14173(6)$ & $0.0190(3)$ \\
\hline $\mathrm{H} 21 \mathrm{~A}$ & -0.1605 & 0.5056 & -0.1563 & $0.023^{*}$ \\
\hline $\mathrm{H} 21 \mathrm{~B}$ & -0.3432 & 0.4701 & -0.1595 & $0.023^{*}$ \\
\hline $\mathrm{C} 22$ & $-0.13580(18)$ & $0.41080(6)$ & $-0.16179(6)$ & $0.0151(3)$ \\
\hline $\mathrm{C} 23$ & $-0.21693(19)$ & $0.37857(7)$ & $-0.21067(6)$ & $0.0177(3)$ \\
\hline $\mathrm{H} 23$ & -0.3274 & 0.3917 & -0.2309 & $0.021^{\star}$ \\
\hline $\mathrm{C} 24$ & $-0.13473(18)$ & $0.32710(7)$ & $-0.22954(6)$ & $0.0170(3)$ \\
\hline $\mathrm{H} 24$ & -0.1906 & 0.3055 & -0.2632 & $0.020^{\star}$ \\
\hline $\mathrm{C} 25$ & $0.09867(19)$ & $0.33775(7)$ & $-0.15481(6)$ & $0.0178(3)$ \\
\hline $\mathrm{H} 25$ & 0.2087 & 0.3235 & -0.1351 & $0.021^{*}$ \\
\hline $\mathrm{C} 26$ & $0.02608(19)$ & $38958(7)$ & $-0.13356(6)$ & $0.0181(3)$ \\
\hline $\mathrm{H} 26$ & 0.0855 & 0.4106 & -0.1001 & $0.022^{\star}$ \\
\hline
\end{tabular}

Table 2 (continued)

\begin{tabular}{lrrrr}
\hline Atom & $\boldsymbol{x}$ & $\boldsymbol{y}$ & $\boldsymbol{z}$ & $\boldsymbol{U}_{\text {iso }} \boldsymbol{U}_{\text {eq }}$ \\
\hline $\mathrm{C} 27$ & $0.1434(2)$ & $0.33521(8)$ & $0.01795(7)$ & $0.0266(3)$ \\
$\mathrm{C} 28$ & $-0.0085(2)$ & $0.29544(9)$ & $0.00094(8)$ & $0.0355(4)$ \\
$\mathrm{H} 28 \mathrm{~A}$ & -0.0245 & 0.2686 & 0.0339 & $0.053^{*}$ \\
$\mathrm{H} 28 \mathrm{~B}$ & 0.0099 & 0.2698 & -0.0326 & $0.053^{*}$ \\
$\mathrm{H} 28 \mathrm{C}$ & -0.1130 & 0.3212 & -0.0100 & $0.053^{*}$ \\
\hline
\end{tabular}

\section{Source of material}

The $\mathrm{Zn}\left[\mathrm{S}_{2} \mathrm{P}(\mathrm{O}-\mathrm{iPr})_{2}\right]_{2}$ precursor was prepared in high yield from the in situ reaction of $\mathrm{Zn}\left(\mathrm{NO}_{3}\right)_{2} \cdot 6 \mathrm{H}_{2} \mathrm{O}$ (Alfa Aesar; $14.87 \mathrm{~g}, 0.05 \mathrm{~mol}$ ), iPrOH (Merck; $16.05 \mathrm{~mL}, 0.21 \mathrm{~mol}$ ), $\mathrm{P}_{2} \mathrm{~S}_{5}$ (Sigma-Aldrich; $11.11 \mathrm{~g}, 0.05 \mathrm{~mol}$ ) and 50\% w/w NaOH solution (Merck; $8.80 \mathrm{~mL}, 0.11 \mathrm{~mol}$ ). $N, N$-Bis(pyridin-4-ylmethyl) ethanediamide $\left({ }^{4} \mathrm{LH}_{2}\right)$ was prepared in high yield from the 2:1 reaction (reflux) of 4-picolylamine (Aldrich; $2.03 \mathrm{~mL}$, $0.02 \mathrm{~mol}$ ) and diethyl oxalate (Aldrich; $1.36 \mathrm{~mL}, 0.01 \mathrm{~mol}$ ) in ethanol solution (Merck; $5 \mathrm{~mL}$ ). The title compound was obtained by mixing a suspension of $\mathrm{Zn}\left[\mathrm{S}_{2} \mathrm{P}(\mathrm{O}-\mathrm{iPr})_{2}\right]_{2}(0.50 \mathrm{~g}$, $1.02 \mathrm{mmol}$ ) and $N, N$-bis(pyridin-4-ylmethyl)ethanediamide (0.28 g, $1.04 \mathrm{mmol}$ ) in dimethylformamide (Merck; $5 \mathrm{~mL}$ ), followed by stirring for $30 \mathrm{~min}$ at $373 \mathrm{~K}$. The solution was filtered, the filtrate taken in acetonitrile (Merck; $1 \mathrm{~mL}$ ) and transferred to a vial for crystallisation. Yellow crystals formed after one day. Yield: $0.5432 \mathrm{~g},\left(69.9 \%\right.$, based on $\mathrm{Zn}\left[\mathrm{S}_{2} \mathrm{P}(\mathrm{O}-\right.$ iPr $\left.)_{2}\right]_{2}$ ). M. pt (Stuart SMP 30 Melting point apparatus): 380.0-381.1 K. IR (Bruker Vertex 70 V equipped with a Platinum ATR from 400 to $\left.80 \mathrm{~cm}^{-1}\right)$ : 1177(w) $v(\mathrm{C}-0)$; 1029(w) $v(\mathrm{P}-0) ; 665(\mathrm{~s}) v(\mathrm{P}-\mathrm{S})_{\text {asym }} ; 530(\mathrm{~m}) v(\mathrm{P}-\mathrm{S})_{\text {sym }}$.

\section{Experimental details}

The C-bound $\mathrm{H}$ atoms were geometrically placed ( $\mathrm{C}-$ $\mathrm{H}=0.95-0.99 \AA$ ) and refined as riding with $U_{\text {iso }}(\mathrm{H})=1.2-$ $1.5 U_{\text {eq }}(\mathrm{C})$. The $\mathrm{N}$-bound $\mathrm{H}$ atoms were refined with $\mathrm{N}-\mathrm{H}=0.88 \pm 0.01 \AA$, and with $U_{\text {iso }}(\mathrm{H})=1.2 U_{\text {eq }}(\mathrm{N})$.

\section{Comment}

The bis[(pyridin- $n$-yl)methyl]ethanediamides, i.e. molecules of the general formula $\left(n-\mathrm{C}_{5} \mathrm{H}_{4} \mathrm{~N}\right) \mathrm{CH}_{2} \mathrm{~N}(\mathrm{H}) \mathrm{C}(=\mathrm{O}) \mathrm{C}(=\mathrm{O})$ $\mathrm{N}(\mathrm{H}) \mathrm{CH}_{2}\left(\mathrm{C}_{5} \mathrm{H}_{4} \mathrm{~N}-\mathrm{n}\right)$, for the $\mathrm{n}=2,3$ and 4 isomers, abbreviated as ${ }^{\mathrm{n}} \mathrm{LH}_{2}$, attract attention for their diverse structural chemistry as co-crystals, salts and metal complexes [5]. As part of on-going studies of the ability of these molecules to coordinate zinc-triad elements, the presence of two pyridyl residues suggests an ability to bridge metal atoms $[5,6]$. Further, the central di-amide group leads to the possibility of forming strong hydrogen bonding interactions to facilitate supramolecular assemblies. In the context of the zinc-triad elements, ${ }^{4} \mathrm{LH}_{2}$ has been shown to 
coordinate a zinc dithiocarbamate $\left({ }^{-} \mathrm{S}_{2} \mathrm{CNR}_{2}\right)$, as in binuclear $\left[\mathrm{Zn}\left(\mathrm{S}_{2} \mathrm{CNEt}_{2}\right)_{2}\right]_{2}\left({ }^{4} \mathrm{LH}_{2}\right)$ [7], and zinc xanthates $\left({ }^{-} \mathrm{S}_{2} \mathrm{COR}\right)$ [8]. For the latter, depending on the bulk of the R group, different aggregation patterns could be observed mirroring the analogous chemistry with 1,2-bis(4-pyridyl)ethylene [9]. Thus, when $\mathrm{R}=\mathrm{Et}$, a twisted chain, i.e. $\left[\mathrm{Zn}\left(\mathrm{S}_{2} \mathrm{COEt}\right)_{2}\left({ }^{4} \mathrm{LH}_{2}\right)\right]_{\mathrm{n}}$, was seen in the crystal. However, when the steric bulk of $\mathrm{R}$ was increased to cyclohexyl (Cy), only a binuclear aggregate could be isolated, i.e. $\left[\mathrm{Zn}\left(\mathrm{S}_{2} \mathrm{COCy}\right)_{2}\right]_{2}\left({ }^{4} \mathrm{LH}_{2}\right)$ [8]. Herein, in continuation of studies in this area, the crystal and molecular structures of a zinc(II) dithiophosphate $\left({ }^{-} \mathrm{S}_{2} \mathrm{P}(\mathrm{OR})_{2}\right)$ derivative, namely $\left.\left\{\mathrm{Zn}\left[\mathrm{S}_{2} \mathrm{P}(\mathrm{O}-\mathrm{iPr})_{2}\right)_{2}\right]_{2}\left({ }^{4} \mathrm{LH}_{2}\right)\right\}_{\mathrm{n}}$, (I) is described.

The asymmetric unit of I excluding the acetonitrile molecule of crystallization, is illustrated in the figure $(70 \%$ probability displacement ellipsoids). The zinc(II) atom is tetrahedrally coordinated by two sulphur atoms, derived from two monodentate dithiophosphate ligands, and two pyridyl-nitrogen atoms, derived from symmetry related ${ }^{4} \mathrm{LH}_{2}$ ligands. The $\mathrm{Zn}-\mathrm{S} 1$ bond length of 2.3014(4) $\AA$ is shorter than the $\mathrm{Zn}-\mathrm{S} 3$ bond of 2.3275(4) A. Both dithiophosphate ligands are orientated with the thione-S2 and S4 atoms oriented towards the zinc(II) atom, rather than the alkoxide atom(s) as is sometimes seen in related systems [10]. However, the $\mathrm{Zn} \cdots \mathrm{S} 2$ and $\mathrm{Zn} \cdots \mathrm{S} 4$ separations of 3.5706(6) and 3.6510(6) A, respectively are not indicative of significant bonding interactions. This conclusion is substantiated by the disparity in the $\mathrm{P}-\mathrm{S}$ bond lengths. Thus, the $\mathrm{P} 1-\mathrm{S} 1$

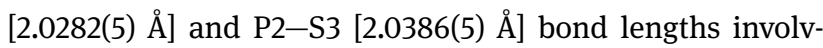
ing the coordinating sulphur atoms are considerably longer

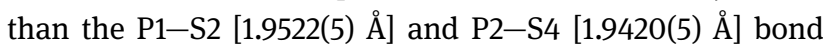
lengths involving the thione-sulphur atoms. Just as there is a difference in the $\mathrm{Zn}-\mathrm{S}$ bond lengths, the $\mathrm{Zn}-\mathrm{N}$ bonds are also different, i.e. $\mathrm{Zn}-\mathrm{N} 1, \mathrm{~N} 4^{\mathrm{i}}=2.0309$ (11) and 2.0611(12) $\AA$, respectively; symmetry operation (i) $x, 1 / 2-y, 1 / 2+z$. The $\mathrm{N}_{2} \mathrm{~S}_{2}$ donor set is based on a tetrahedron with the tetrahedral angles spanning a relatively narrow range, i.e. ranging from a narrow $99.78(3)^{\circ}$, for $\mathrm{S} 3-\mathrm{Zn}-\mathrm{N} 4^{\mathrm{i}}$, to a wide $117.56(1)^{\circ}$ for $\mathrm{S} 1-\mathrm{Zn}-\mathrm{S} 3$. The central $\mathrm{C}_{2} \mathrm{~N}_{2} \mathrm{O}_{2}$ residue is planar exhibiting a r.m.s. deviation of $0.016 \AA$. The dihedral angles between this unit and the N1-and N4-pyridyl rings are 64.56(3) and 76.03(3) A, respectively. The dihedral angle between the two pyridyl rings is $68.76(4)^{\circ}$ and as they lie to the same side of the central plane, the conformation may be described as U-shaped; the conformational flexibility of ${ }^{n} \mathrm{LH}_{2}$ molecules has been commented upon [5]. The central C19-C20 bond is relatively long at $1.5428(18) \AA$, but this phenomenon is well-known and is due to the presence of the electronegative substituents [5].

The lower view of the figure shows the one-dimensional coordination polymer which is propagated by glide symmetry along the $c$-axis. The topology of the chain is zigzag with pairs of successive zinc(II) atoms connected by the curved ${ }^{4} \mathrm{LH}_{2}$ molecules with alternating orientations. In the crystal, the key connection between the coordination polymer and the solvent acetonitrile molecule is an amide$\mathrm{N}-\mathrm{H} \cdots \mathrm{N}$ (acetonitrile) hydrogen bond [N2-H2n $\cdots \mathrm{N} 5^{\mathrm{ii}}$ : $\mathrm{H} 2 \mathrm{n} \cdots \mathrm{N} 5^{\mathrm{ii}}=2.205(14) \AA, \quad \mathrm{N} 2 \cdots \mathrm{N} 5^{\mathrm{ii}}=2.9580(19) \AA \quad$ with angle at $\mathrm{H} 2 \mathrm{n}=145(1)^{\circ}$ for (ii) $\left.-1+x, y, z\right]$. The second amide- $\mathrm{N}-\mathrm{H}$ forms a hydrogen bond to a carbonyl atom $\left[\mathrm{N} 3-\mathrm{H} 3 \mathrm{n} \cdots \mathrm{O} 5^{\mathrm{iii}}\right.$ : $\mathrm{H} 3 \mathrm{n} \cdots \mathrm{O} 5^{\mathrm{iii}}=2.128(14) \AA$, $\mathrm{N} 3 \cdots \mathrm{O} 5^{\mathrm{iii}}=2.9189(16) \AA$ with angle at $\mathrm{H} 3 \mathrm{n}=151(1)^{\circ}$ for (iii) $-x, 1-y,-z]$. The latter weakly connects centrosymmetrically related chains into a double-chain via eight-membered $\left\{\cdots \mathrm{HNCO}_{2}\right.$ synthons. Further aggregation between chains is precluded owing to the interaction of the acetonitrile with the amide residue. The double-chains assemble in the crystal without directional interactions between them.

Acknowledgements: Sunway University Sdn Bhd is thanked for financial support of this work through Grant no. STRRCTR-RCCM-001-2019.

\section{References}

1. Rigaku Oxford Diffraction: CrysAlis ${ }^{\mathrm{PRO}}$. Rigaku Corporation, Oxford, UK (2018).

2. Sheldrick, G. M.: A short history of SHELX. Acta Crystallogr. A64 (2008) 112-122.

3. Sheldrick, G. M.: Crystal structure refinement with SHELXL. Acta Crystallogr. C71 (2015) 3-8.

4. Farrugia, L. J.: WinGX and ORTEP for Windows: an update. J. Appl. Crystallogr. 45 (2012) 849-854.

5. Tiekink, E. R. T.: Multi-component crystals: synthesis, concepts, function. (Eds. Tiekink, E. R. T. and Schpector-Zukerman, J.), p. 289-319. De Gruyter, Singapore (2017).

6. Tiekink, E. R. T.: Perplexing coordination behaviour of potentially bridging bipyridyl-type ligands in the coordination chemistry of zinc and cadmium 1,1-dithiolate compounds. Crystals 8 (2018) 18.

7. Arman, H. D.; Poplaukhin, P.; Tiekink, E. R. T.: Crystal structure of $\left(\mu_{2}-N, N^{\prime}\right.$-bis ((pyridin-4-yl)methyl)ethanediamide$\mathrm{K}^{2} N: N^{\prime}$ )-tetrakis(diethylcarbamodithioato- $\left.{ }^{2} S, S^{\prime}\right)$ dizinc(II), $\mathrm{C}_{34} \mathrm{H}_{54} \mathrm{~N}_{2} \mathrm{O}_{2} \mathrm{~S}_{8} \mathrm{Zn}_{2}$. Z. Kristallogr. NCS 233 (2018) 159-161.

8. Tan, Y. S.; Chun, H. Z.; Jotani, M. M.; Tiekink, E. R. T.: Steric control of supramolecular association in structures of $\mathrm{Zn}\left(\mathrm{S}_{2} \mathrm{COR}\right)_{2}$ with $N, N^{\prime}$-bis(pyridin-4-ylmethyl)oxalamide. Z. Kristallogr. CM 234 (2019) 165-175.

9. Kang, J.-G.; Shin, J.-S.; Cho, D.-H.; Jeong, Y.-K.; Park, C.; Soh, S. F.; Lai, C. S.; Tiekink, E. R. T.: Steric control over supramolecular polymer formation in trans-1,2-bis(4pyridyl)ethylene adducts of zinc xanthates: implications for luminescence. Cryst. Growth Des. 10 (2010) 1247-1256.

10. Tan, Y. S.; Tiekink, E. R. T.: Crystal structure of catena[(bis $\left(O, O^{\prime}\right.$-diethyl dithiophosphato- $\left.S, S^{\prime}\right)-\mu_{2}-1,2-$ bis(3-pyridylmethylene)hydrazine- $\left.N, N^{\prime}\right)$ zinc(II)], $\left\{\mathrm{C}_{20} \mathrm{H}_{30} \mathrm{~N}_{4} \mathrm{O}_{4} \mathrm{P}_{2} \mathrm{~S} \mathrm{Z}_{4} \mathrm{Zn}\right\}_{n}$. Z. Kristallogr. NCS 235 (2020) 297-299. 